\title{
Protein Expression Profiles in an Endosymbiotic Cyanobacterium Revealed by a Proteomic Approach
}

\author{
Martin Ekman, ${ }^{1}$ Petter Tollbäck, ${ }^{2}$ Johan Klint, ${ }^{1}$ and Birgitta Bergman' \\ ${ }^{1}$ Department of Botany, Stockholm University, SE-106 91 Stockholm, Sweden; ${ }^{2}$ Stockholm University Proteomics Facility, \\ Department of Analytical Chemistry, Stockholm University, SE-106 91 Stockholm, Sweden
}

Received 30 March 2006. Accepted 26 June 2006.

\begin{abstract}
Molecular mechanisms behind adaptations in the cyanobacterium (Nostoc sp.) to a life in endosymbiosis with plants are still not clarified, nor are the interactions between the partners. To get further insights, the proteome of a Nostoc strain, freshly isolated from the symbiotic gland tissue of the angiosperm Gunnera manicata Linden, was analyzed and compared with the proteome of the same strain when free-living. Extracted proteins were separated by two-dimensional gel electrophoresis and were identified by matrix-assisted laser desorption/ionization-time of flight mass spectrometry combined with tandem mass spectrometry. Even when the higher percentage of differentiated cells (heterocysts) in symbiosis was compensated for, the majority of the proteins detected in the symbiotic cyanobacteria were present in the free-living counterpart, indicating that most cellular processes were common for both stages. However, differential expression profiling revealed a significant number of proteins to be down-regulated or missing in the symbiotic stage, while others were more abundant or only expressed in symbiosis. The differential protein expression was primarily connected to i) cell envelope-associated processes, including proteins involved in exopolysaccharide synthesis and surface and membrane associated proteins, ii) to changes in growth and metabolic activities ( $C$ and $N$ ), including upregulation of nitrogenase and proteins involved in the oxidative pentose phosphate pathway and downregulation of Calvin cycle enzymes, and iii) to the dark, microaerobic conditions offered inside the Gunnera gland cells, including changes in relative phycobiliprotein concentrations. This is the first comprehensive analysis of proteins in the symbiotic state.
\end{abstract}

Cyanobacteria belonging to the filamentous and heterocystous genus Nostoc form symbiotic associations with a range of land plants from fungi to gymnosperms, but the genus Gunnera is the only flowering plant (angiosperm) (Rai et al. 2000). This is also the only plant symbiosis in which the cyanobacterium is located intracellularly and therefore shares similarities with the ancestral cyanobacterial symbiosis that led to the evolution of plant chloroplasts (Martin et al. 2002; Schopf 2000).

The symbiotic organs colonized by cyanobacteria in Gunnera plants are specialized stem glands (Bergman 2002; Bergman et al. 1992). When not yet infected, the glands secrete mucilage that attract Nostoc spp. and induce differentiation of vegetative filaments into motile hormogonia. The hormogonia enter the gland interior through channels and subsequently infect certain Gunnera cells, in which they revert into nonmotile vegetative filaments (Johansson and Bergman 1992). Simultaneously, the differentiation of nitrogen-fixing heterocysts is profoundly stimulated (Rai et al. 2000), reflected in a severalfold increase in hetR expression (Wang et al. 2004), the product of which is required for heterocyst development (Buikema and Haselkorn 1991). Frequencies of up to 70 to $80 \%$ heterocysts have been observed in Nostoc spp. residing in older parts of the plant, as compared with 5 to $10 \%$ in young parts and in free-living Nostoc spp. The increase in heterocyst frequency is accompanied by increased nitrogen fixation activities, and most of the fixed nitrogen is released by the Nostoc cells and assimilated by the host plant (Silvester et al. 1996). This release is due to a reduced glutamine synthetase activity, the primary nitrogen assimilation enzyme in cyanobacteria (Söderbäck 1992). In return, the cyanobacteria are fed by fixed carbon from the plant, being photosynthetically inactive in the dark interior of the Gunnera glands (Black et al. 2002; Söderbäck and Bergman 1992). Other observed symbiotic modifications include enlargement of the Nostoc cell volume, interpreted as a blocked cell division possibly induced by the plant as a means of restricting growth of the cyanobacterium. The physiological adaptations are influenced by gland age (Söderbäck and Bergman 1992, 1993; Söderbäck et al. 1990). The highest frequency of heterocysts is restricted to older glands, and the expression of certain cyanobacterial genes, such as hetR, ntcA, and nifH, involved in cell differentiation and in nitrogen metabolism, show varied expression patterns along the gland age gradient (Wang et al. 2004).

The aim of the present study was to get a more holistic insight into mechanisms underlying the morphological and metabolic transformation of a free-living Nostoc sp. into a fully competent plant cyanobiont. The approach taken was to compare the expression patterns and the relative quantities of a large number of individual proteins in a fully adapted cyanobiont in Gunnera manicata versus in the corresponding free-living cyanobacterium. To achieve this aim, two-dimensional (2-D) gel electrophoresis and matrix-assisted laser desorption/ionization-time of flight mass spectrometry (MALDI-TOF/MS) combined with electrospray-tandem mass spectrometry (MS/MS) were used.

\section{RESULTS AND DISCUSSION}

Genetic identity

of the cyanobiont and its free-living counterpart.

The cyanobacteria infecting Gunnera spp. are morphologically classified as belonging to the genus Nostoc (Bergman 
2002; Rai et al. 2000). Previous studies have shown that most Gunnera plants are infected by single Nostoc strains (Guevara et al. 2002), although additional cyanobacterial strains may occur within the same plant (Nilsson et al. 2000). For comparing the proteomes of Nostoc filaments residing endosymbiotically in Gunnera manicata cells (cyanobionts) with those in the corresponding free-living Nostoc sp., it was crucial to verify the genetic identity of the strains. A polymerase chain reaction (PCR)-based DNA fingerprinting method, based on the presence of short tandemly repeated repetitive (STRR) sequences in the Nostoc genome, was used for this purpose. The cyanobacterium-specific STRR1A primers used give a resolution at the strain level (Rasmussen and Svenning 1998). The STRR-PCR fingerprints of freshly dissected Nostoc cyanobionts from two differently aged stem sections (young and old) of one G. manicata plant is illustrated in Figure 1 (A1 and A2). Approximately 35 glands were pooled at each age stage. As the DNA fingerprint patterns were identical at the two age stages, it was concluded that the one or more Nostoc strains were uniform throughout the plant. The free-living Nostoc strain AF, isolated from the symbiotic sample A1, also showed an identical fingerprint pattern (Fig. 1; lane AF). However, clearly different DNA fingerprints were obtained from freshly isolated Nostoc cells dissected from the smaller stoloniferous G. magellanica growing in the same greenhouse (Fig. 1; B1 and B2), from its free-living cultured counterpart (Fig. 1; BF), as well as from the cultured Nostoc strain PCC 9229 (originally isolated from G. monoica) (Fig. 1). Sequencing of the tRNA ${ }^{\text {Leu }}$ (UAA) intron of the cyanobiont of $G$. manicata (A1 and A2) and the freeliving strain (AF), a sequence previously used to distinguish between cyanobacteria (Paulsrud and Lindblad 1998), produced identical sequences, thus supporting the identity between A1 and A2 and AF (data not shown).

\section{Differential protein profiles \\ in symbiotic and free-living Nostoc spp.}

The symbiotic Nostoc material used for the extraction of total proteins (using a buffer containing urea, thiourea, dithiothreitol [DTT], and 3-[(3-cholamidopropyl)-dimethyl-ammonio]-1propanesulfonate [CHAPS], as described below) was composed of a mixture of equal amounts of the above-characterized freshly isolated samples, A1 and A2, therefore representing both young and older Gunnera gland cyanobionts. The heterocyst frequency in this material averaged about $30 \%$. The protein extracts of the cyanobiont and the free-living counterpart $\mathrm{AF}$ were separated by 2-D gel electrophoresis covering a $\mathrm{pH}$ range of 4 to 7. As seen in Figure 2A and B, approximately 200 proteins from the cyanobiont and the free-living Nostoc sample (AF) could be visualized on SyproRuby-stained 2-D gels. The majority of the cyanobiont protein spots were also present in the free-living Nostoc sample, although some clear differences could be verified. Several proteins appeared to be down-regulated in the cyanobiont, while others were up-regulated.

A total of 56 protein spots that were repeatedly more than two times up-regulated (36 spots) or more than two times down-regulated (20 spots) were analyzed by MALDITOF/MS, and 30 of these were identified. Since MALDI$\mathrm{TOF} / \mathrm{MS}$ is dependent on a high degree of sequence similarity between the investigated protein and the database protein, even high quality MALDI-TOF spectra may be insufficient for identifying proteins from unsequenced organisms. Therefore, in order to expand the identification, eight of the unidentified proteins were further analyzed by MS/MS, which is less sensitive to differences in protein sequence (Shevchenko et al. 2001). This allowed the identification of three additional proteins, and one protein was identified by both MALDI-TOF/MS and MS/MS. Hence, a total of 33 of the analyzed spots were identified (Table
1, Fig. 2). Three of the proteins resolved into two different spots (g7-8, g9-10, and g21-22; Table 1), possibly due to posttranslational modifications of the proteins in question.

In an earlier study using $G$. manicata but with a different cyanobiont, 15 differentially expressed proteins were identified (data not shown). Seven of these were identified also in the present study and showed similar expression patterns. Five were not identified here, possibly because a narrower $\mathrm{pH}$ range was used in the previous study. These spots are, therefore, not marked on any gels but are still included in Table 1 (proteins $\mathrm{gI}$ to $\mathrm{gV}$ ). As the remaining three proteins did not change in abundance in the present study, these were not included here.

One reason for the difficulty in identifying additional proteins is probably that the symbiotic Nostoc strain examined is not identical to the cultivated and symbiotically competent Nostoc strain PCC 73102, of which the whole genome sequence is used as the basis for the protein identifications (available online from the Department of Energy, Joint Genome Institute). This is supported by the finding that all proteins isolated from heterocysts of Nostoc strain PCC 73102 could be identified (discussed below). The fact that more than $50 \%$ of the proteins examined were identified using peptide mass fingerprinting demonstrates a close relatedness between Nostoc strain PCC 73102 and the cyanobiont examined here and also points to the potential for using the proteomic approach to study nonsequenced cyanobionts in other natural plant symbioses. Using MS/MS in parallel increases both the confidence of identifications and the number of identified proteins.

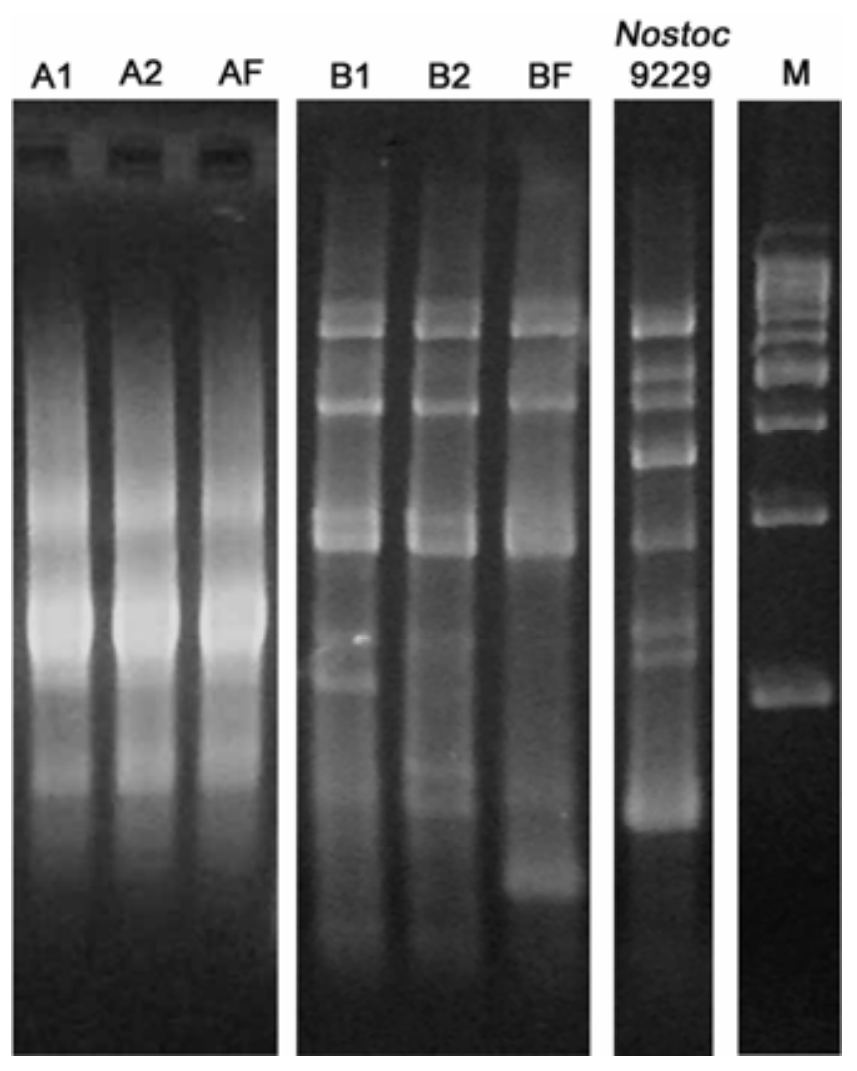

Fig. 1. Short tandemly repeated repetitive polymerase chain reaction fingerprinting of symbiotic and free-living Nostoc strains. Lanes A1 and A2 represent symbiotic Nostoc cells freshly dissected from glands of two different age stages (young and old) of one Gunnera manicata plant. AF represents a cultured free-living strain isolated from A1. B1 and B2 represent symbiotic Nostoc cells freshly dissected from the smaller G. magellanica. $\mathrm{BF}$ is a cultured free-living strain isolated from G. magellanica. Nostoc PCC 9229 is a free-living strain isolated from G. monoica in 1992. M indicates the molecular weight standard. 
Protein patterns in heterocysts versus vegetative cells.

Given the often severalfold elevated frequency of heterocysts in cyanobionts compared with free-living cyanobacteria, it was necessary to first compare the overall protein patterns in vegetative cells and heterocysts to estimate the contribution of heterocysts to the protein changes seen in the cyanobiont. The protein patterns obtained after separating proteins from a vegetative cell fraction and a heterocyst-enriched fraction (approximately $80 \%$ heterocysts) of the cultured Nostoc strain PCC 73102 were compared. As seen in Figure $3 \mathrm{~A}$ and B, the majority of the proteins in the vegetative cells also appeared in the heterocysts. However, some proteins were down-regulated, a few were clearly up-regulated, and some were only present in the heterocyst protein fraction. In total, eight spots that were present only in the heterocyst were analyzed by MALDITOF/MS (Fig. 3; Table 2). As expected, proteins of the nitrogenase enzyme were exclusive to the heterocyst-enriched fraction. Five other proteins ( $\mathrm{h} 1$ to $\mathrm{h} 4$ and $\mathrm{h} 6$ ) were associated with cell envelope functions, which is logical, as heterocysts have additional cell envelope layers, an outer polysaccharide layer, and an inner glycolipid layer, added to their original gram-negative cell wall (Wolk et al. 1994). One DNA-binding ferritin (h7) was also highly up-regulated in the heterocyst preparation. This protein was absent in vegetative (ammoniagrown) cultures but present in $\mathrm{N}$-deficient $\left(\mathrm{N}_{2}\right.$-fixing) cultures (data not shown). This shows that this ferritin responds to nitrogen limitation, and indeed, this gene has an NtcA binding sequence at -113 , a transcription factor influencing the expression of N-regulated genes in cyanobacteria (Flores and Herrero 2005). One of the enzymes specific for the oxidative pentose phosphate pathway, 6-phosphogluconte dehydrogenase (6PGD) (h8), was also up-regulated. It has previously been shown that this pathway has an important function in providing reductant for nitrogen fixation in heterocysts (Summers et al. 1995). It should be noted that the frequency of heterocysts in the Gunnera cyanobiont was less than half of that in the heterocystenriched fraction of Nostoc strain PCC 73102 examined.

\section{Proteins affected in the cyanobiont.}

As seen in Figure 2 and Table 2, several cyanobacterial proteins were affected by the symbiotic conditions prevailing in Gunnera manicata. Of the proteins identified, 23 were up-regulated in the cyanobiont in the plant while 10 were down-regulated.

\section{Cell envelope and extracellular carbohydrates.}

Four of the up-regulated proteins were surface- or membraneassociated (g3, g16, g26, gII; Table 1). One of these (g3) contained fasciclin-like repeats. A protein with such repeats was earlier identified to be highly up-shifted in the Nostoc cyanobiont of a lichen symbiosis and was suggested to have a role in symbiosis (Paulsrud and Lindblad 2002). However, as this protein was also up-regulated in heterocysts, as was protein g16, the high level of the fasciclins in symbiosis may rather be caused by the high heterocyst frequency. In the genome of symbiotically-competent Nostoc strain PCC 73102, the geneencoding protein gII is located just downstream of a sugar uptake operon. This operon was induced in Nostoc strain PCC 73102 when grown on fructose in darkness (data not shown), indicating that fructose may be the carbohydrate supplied by the host.

Three of the downregulated proteins are known to be involved in exopolysaccharide (EPS) and lipopolysaccharide (LPS) synthesis in bacteria. These were UDP-glucose 6-dehydrogenase (g21, 22) (Kereszt et al. 1998; Xue et al. 2004) and two phosphomanno-mutases (g27 and g30) (Bahat-Samet et al. 2004; Coyne et al. 1994). Such data are supported by examinations of the Gunnera cyanobiont and its free-living counterpart by light (Fig. 4) and transmission electron microscopy (Figs. 4E and 5). In symbiosis, the cyanobiont showed larger cells, more convoluted filaments, and a higher heterocyst frequency, while Alcian blue staining demonstrated that it produces considerably less EPS (Fig. 4, A compared with C). Moreover, the fibrillar nature of the heterocyst envelope and a thinner polysaccharide layer was evident in heterocysts of the cyanobiont after

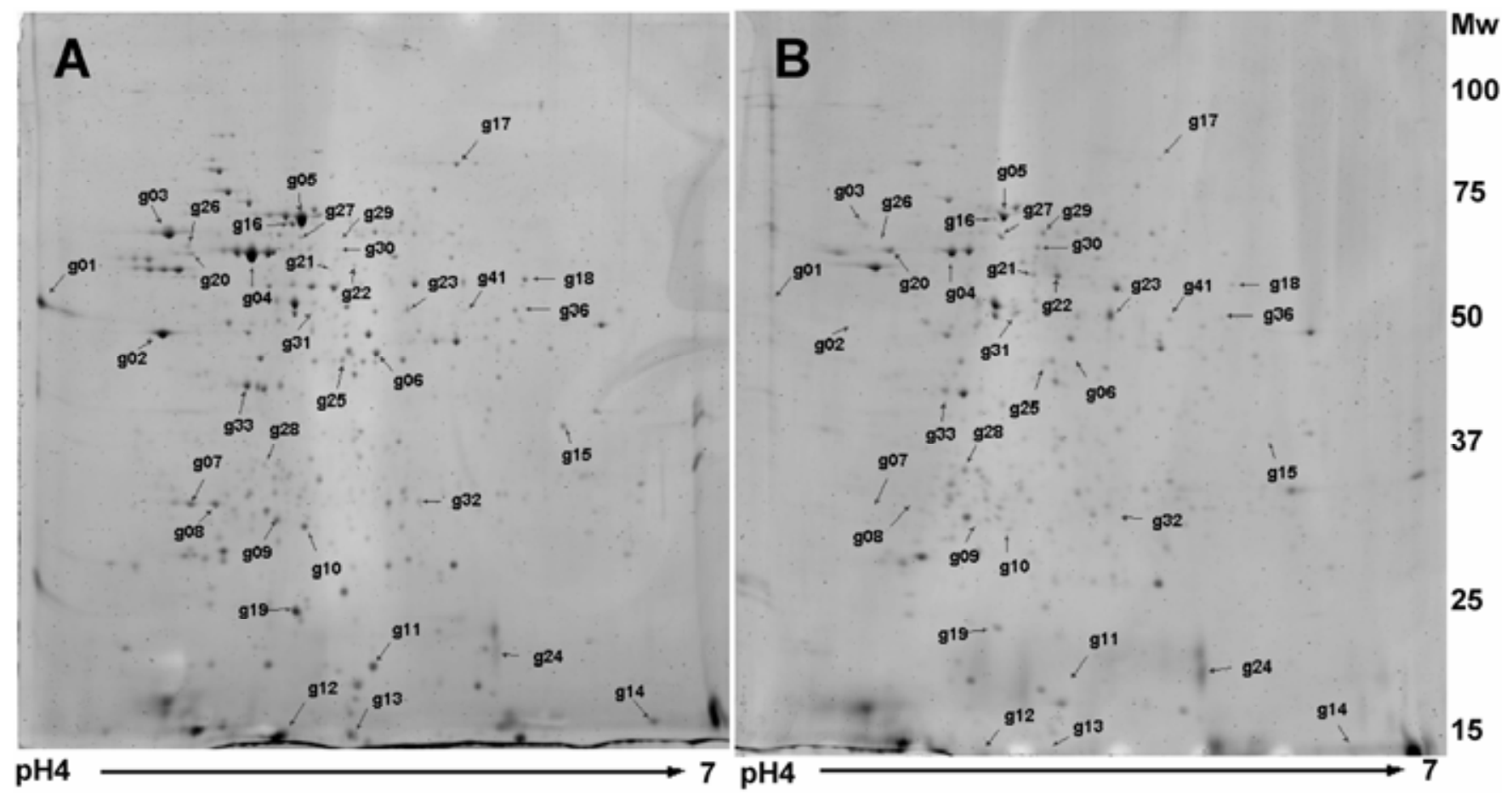

Fig. 2. Protein patterns in extracts of A, freshly isolated symbiotic Nostoc cells of Gunnera maincata and B, its free-living counterpart Nostoc AF. Proteins were separated by two-dimensional gel electrophoresis, using a pH gradient of 4 to 7 and $10 \%$ sodium dodecyl sulfate-polyacrylamide gel electrophoresis and staining with Sypro Ruby. 
Table 1. Proteins differentially expressed in symbiotic compared with free-living Nostoc strains

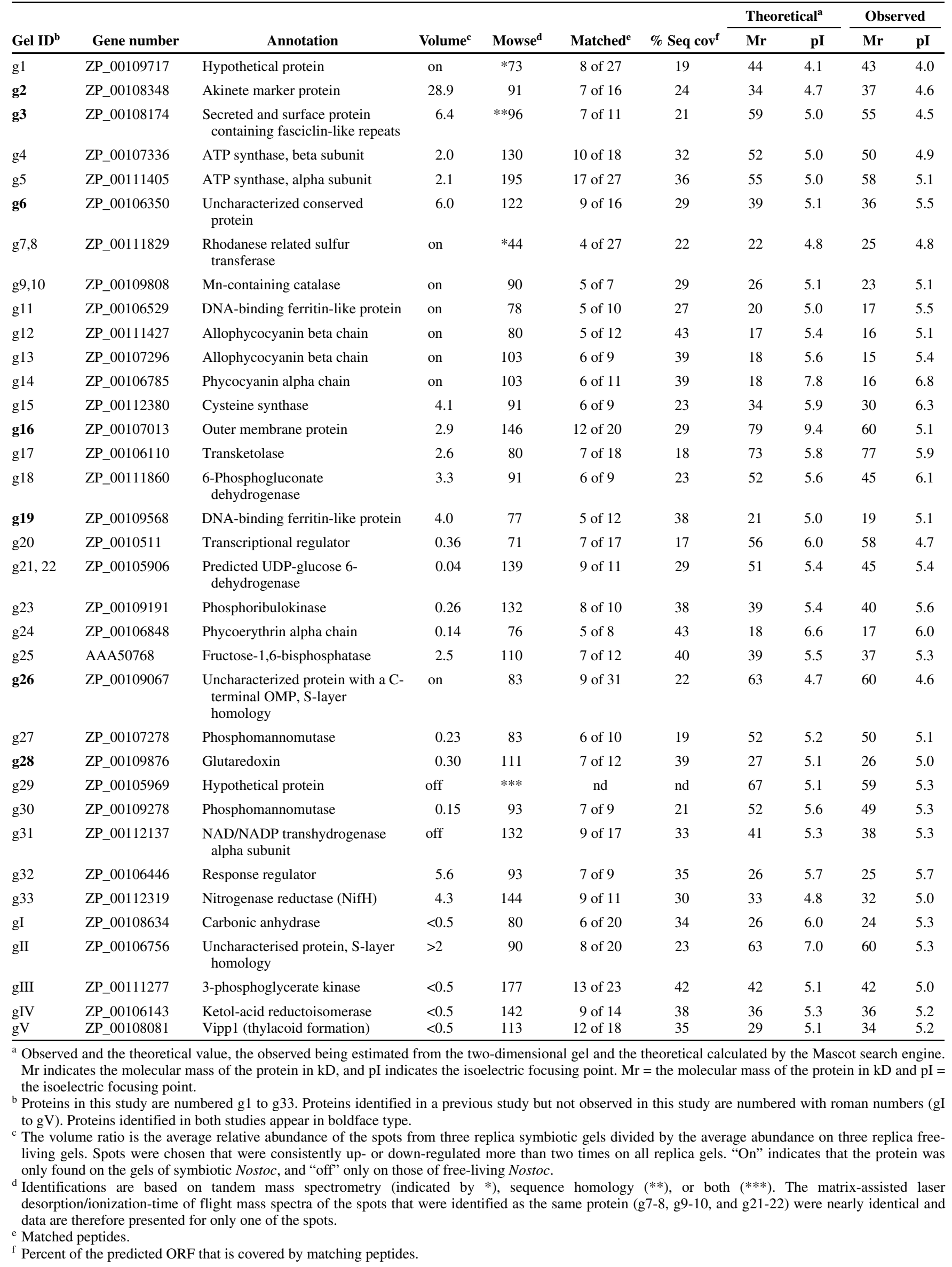


Ruthenium red staining (compared in Figs. 4E and 5). LPS and EPS may have partly common biosynthetic pathways, and it has been speculated that the EPS layer of heterocysts may itself be an LPS (Huang et al. 2005). Furthermore, a protein (g20) containing the conserved LytR domain was down- regulated in the cyanobiont. Proteins containing this domain are transcriptional regulators involved in biosynthesis of extracellular polysaccharides, fimbriation, expression of exoproteins, including toxins, and in quorum sensing (Nikolskaya and Galperin 2002). However, proteins containing this domain have also been shown to be involved in cell division (Chatfield et al. 2005). The lower Mowse score of this protein (71) should be noted, and a confirmation of the identity and role of this protein is needed.

A reduced production of extracellular polysaccharides could be caused by differences in $\mathrm{C} / \mathrm{N}$ ratios (Otero and Vincenzini 2004), the absence of light (Otero and Vincenzini 2003), or by the microaerobic conditions prevailing inside the infected plant tissues (data not shown). For instance, the downregulation of the phosphomannomutase gene seen here has also been observed in Pseudomonas aeruginosa under low-oxygen conditions (Leitao and Sa-Correia 1997). The glycolipid layer of heterocysts is also known to decrease in thickness with decrease in oxygen concentration (Kangatharalingam et al. 1992). Modifications of the glycolipid or polysaccharide layer of heterocysts may be involved in the release of the nitrogen fixed (up to $90 \%$ ) by the cyanobiont and may also explain the oxygensensitive nitrogen fixation of freshly isolated cyanobionts (Rai et al. 2000; Silvester et al. 1996).

\section{Dark response.}

The dark interior of the Gunnera glands is reflected in a modified phycobiliprotein composition of the cyanobiont. As seen in Figure 2 and Table 1, allophycocyanin (g12 and g13)

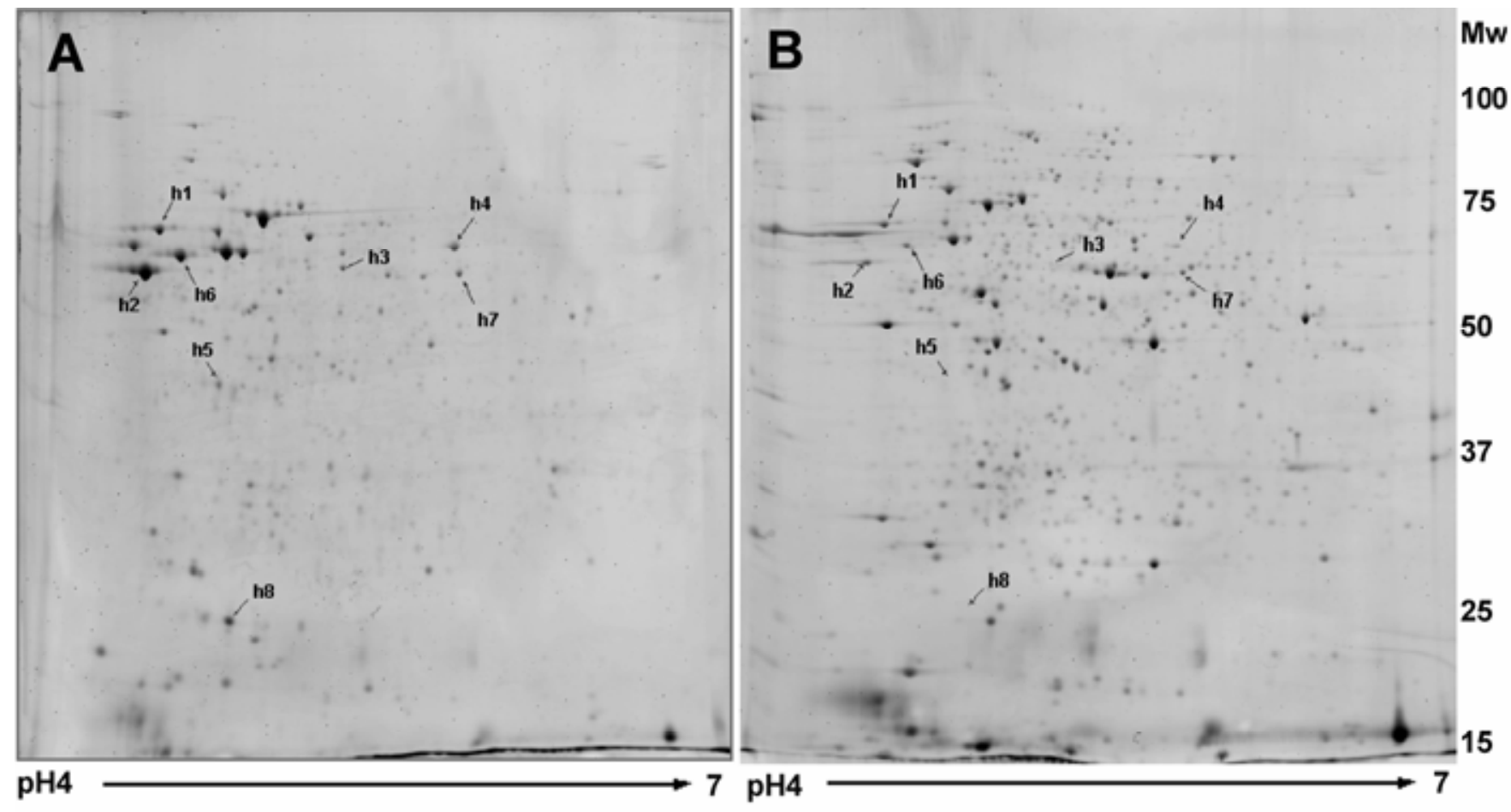

Fig. 3. Protein patterns in extracts of A, heterocyst enrichment and B, vegetative cells of Nostoc strain PCC 73102. Proteins were separated by -dimensional gel electrophoresis using a $\mathrm{pH}$ gradient of 4 to 7 and $10 \%$ sodium dodecyl sulfate-polyacrylamide gel electrophoresis and staining with Sypro Ruby.

Table 2. Proteins up-regulated in heterocysts of Nostoc strain PCC 73102

\begin{tabular}{|c|c|c|c|c|c|c|c|c|c|}
\hline \multirow[b]{2}{*}{ Gel ID } & \multirow[b]{2}{*}{ Gene number } & \multirow[b]{2}{*}{ Annotation } & \multirow[b]{2}{*}{ Mowse score } & \multirow[b]{2}{*}{ Matched peptides } & \multirow[b]{2}{*}{$\%$ Seq $\operatorname{cov}^{b}$} & \multicolumn{2}{|c|}{ Theoretical $^{\mathrm{a}}$} & \multicolumn{2}{|c|}{ Observed } \\
\hline & & & & & & Mr & pI & Mr & pI \\
\hline h1 & ZP_00108174 & $\begin{array}{l}\text { Secreted and surface protein containing } \\
\text { fasciclin-like repeats }\end{array}$ & 90 & 8 of 19 & 2 & 59 & 5.0 & 60 & 4.6 \\
\hline h2 & ZP_00106112 & Autotransporter adhesin & 96 & 9 of 27 & 28 & 62 & 4.9 & 50 & 4.5 \\
\hline h3 & ZP_00107013 & Outer membrane protein & 186 & 12 of 13 & 30 & 79 & 9.4 & 50 & 5.4 \\
\hline h4 & ZP_00110600 & $\begin{array}{l}\text { Periplasmic protein involved in } \\
\text { polysaccharide export }\end{array}$ & 112 & 9 of 17 & 25 & 51 & 7.8 & 55 & 5.9 \\
\hline h5 & ZP_00112319 & Nitrogenase reductase (NifH) & 83 & 8 of 13 & 22 & 33 & 4.8 & 37 & 4.9 \\
\hline h6 & ZP_00108185 & Hypothetical protein S-layer & 259 & 18 of 26 & 52 & 60 & 4.8 & 50 & 4.7 \\
\hline h7 & ZP_00109568 & DNA-binding ferritin & 105 & 8 of 18 & 43 & 21 & 5.0 & 22 & 4.9 \\
\hline $\mathrm{h} 8$ & ZP_00111860 & 6-Phosphogluconate dehydrogenase & 116 & 8 of 11 & 30 & 58 & 5.5 & 60 & 5.7 \\
\hline
\end{tabular}

${ }^{a}$ The observed value was estimated from the two-dimensional gel. The theoretical value was calculated by the Mascot search engine. Mr indicates the molecular mass of the protein in $\mathrm{kD}$, and $\mathrm{pI}$ indicates the isoelectric focusing point.

${ }^{b}$ Percent of the predicted ORF that is covered by matching peptides. 
and phycocyanin (g14) levels were up-regulated, while phycoerythrin was down-regulated as compared with that in the freeliving counterpart. The bluer pigmentation of the cyanobiont was obvious using light microscopy (Fig. 4D), and spectrophotometric absorbance wavelength scanning showed a relatively higher absorption around $620 \mathrm{~nm}$ (phycocyanin) and a lower at 560 (phycoerythrin) (Fig. 6A). After normalizing these levels to chlorophyll a concentrations, the free-living Nostoc strain had about equal levels of the pigments, while the cyanobiont phycoerythrin level was only about half that of phycocyanin and allophycocyanin (Fig. 6B). A decrease in phycoerythrin levels was also observed for Nostoc strain Mac grown in darkness, a change also expected for chromatic adaptation to red light (Austin et al. 1996). The downregulation of Vipp1 ( $\mathrm{gV}$ in the cyanobiont [Table 1]), a protein needed for thylakoid membrane synthesis in Synechocystis sp. strain PCC 6803 (Westphal et al. 2001), may also be a reflection of the dark interior of the Gunnera gland tissues.

\section{Energy, nitrogen, and carbon metabolism.}

As seen in Table 1, the dinitrogenase reductase (NifH) (g33) level was approximately four times higher in the cyanobiont than in the free-living counterpart, which is in accordance with previous studies using immuno-cytochemistry and the higher

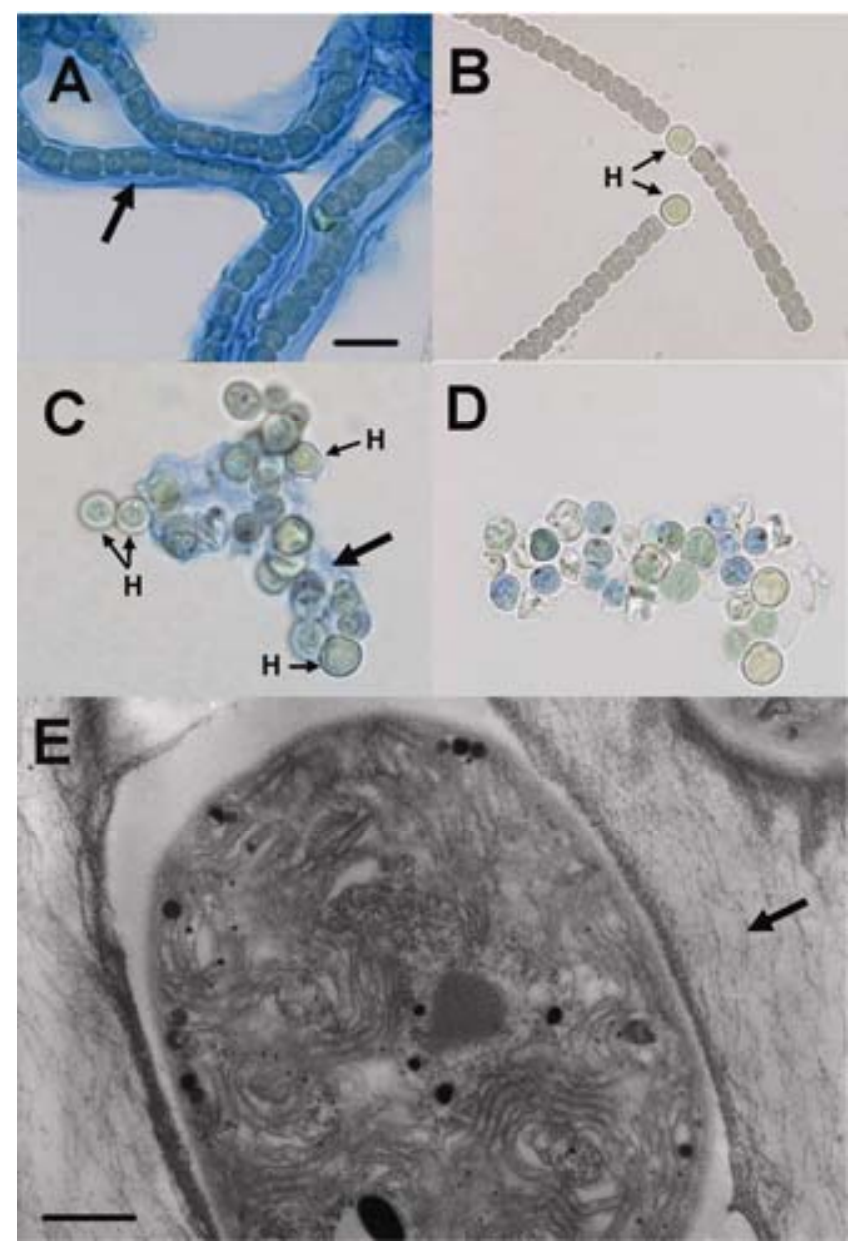

Fig. 4. Light microscopic images of Alcian blue-stained exopolysaccharides (EPS) of the $\mathbf{A}$, cultured and $\mathbf{C}$, symbiotic Nostoc (Gunnera manicata) cells demonstrating more pronounced EPS layers (thick arrows) in the free-living stage. B and D, Nonstained controls. E, transmission electron micrograph of a ruthenium red-stained free-living Nostoc cell showing the fibrillar nature of the EPS layer (arrow). Note the higher heterocyst (H) frequency in the cyanobiont. Scale bars represent $15 \mu \mathrm{m}$ (A to D) and $1 \mu \mathrm{m}(\mathrm{E})$. rates of nitrogen fixation observed in Gunnera symbioses (Söderbäck et al. 1990). Since nitrogen fixation is a highly energy-demanding process, mechanisms involved in supplying ATP are central to symbiosis. This may explain the high levels of ATP synthase detected (Fig. 2 and Table 1; g4 and g5) and suggests that oxidative phosphorylation is crucial for ATP production in the cyanobiont.

6PGD (Fig. 1 and Table 1; g18) is one of the key enzymes of the oxidative pentose phosphate (OPP) pathway. The fact that this enzyme was up-regulated in the cyanobiont stresses the importance of this pathway for oxidizing plant-supplied carbohydrates. This is also supported by previous reports on dark heterotrophic growth of Nostoc sp strain ATCC 29133 (Summers et al. 1995). As the same protein was up-regulated in heterocysts (Table 2), the upregulation in the cyanobiont may be associated with the higher heterocyst frequency in symbiosis. Indeed, OPP is the main pathway for producing reducing equivalents for nitrogen fixation (Wolk et al. 1994). Alternatively, the upregulation of 6PGD may also be associated with the reduced growth rate in symbiosis, since expression of 6PGD in Synechococcus sp. strain PCC 7942 is known to be growth-phase dependent (Broedel and Wolf 1991).

Glucose-6-phosphate dehydrogenase (G6PD) is also specific for the OPP pathway. The gene encoding G6PD is located in an operon containing genes encoding transaldolase and fructose-1,6-bisphosphatase (FBP) (Fig. 1 and Table 1; g25), and FBP is known to be up-regulated under diazotrophic conditions (Summers and Meeks 1996). There are two types of FBP in cyanobacteria, the commonly expressed FBP with sedoheptulose-1,7-bisphosphatase (SBP) activity and the FBP of the operon mentioned above (Tamoi et al. 1998). Our data show that FBP of the G6PD operon is up-regulated in the cyanobiont and may therefore have a specific function for the OPP pathway in heterocysts, in combination with dark heterotrophic growth conditions, or both. This FBP may be replaced by the FBP and SBP under photoautotrophic conditions or in vegetative cells. Transketolase ( $\mathrm{g} 17)$ is an enzyme common for the OPP pathway and the Calvin cycle. As this enzyme is up-regulated in the cyanobiont while the Calvin cycle is inactive (Söderbäck and Bergman 1992), also reflected in the downregulation of one of the key enzymes of the cycle, phosphoribulokinase (g23), the importance of the OPP pathway under symbiotic conditions is again stressed.

Intermediates of glycolysis are, however, also present in glucose-supplied gland tissue (Black et al. 2002) suggesting that the OPP pathway is not the only pathway active in catabolizing sugars in the Gunnera symbiosis, Phosphoglycerate kinase (gIII) is common for both glycolysis and the Calvin cycle. The downregulation detected here may therefore reflect a reduced carbon flow through glycolysis or an inactive Calvin cycle. Downregulation of certain other metabolic enzymes, such as NAD/NADP transhydrogenase (kb31) and ketol-acid reductoisomerase (gIV), may be related to the reduced growth rate, a switch to a low-oxygen adapted metabolism, or to the reduced percentage of vegetative cells.

Being photosynthetically inactive, the upshift in carbonic anhydrase (Table 1, gI) is not likely associated with providing high concentrations of $\mathrm{CO}_{2}$ at Rubisco and suggests one or more still-unknown roles for this enzyme in cyanobacteria. Indeed, the most homologous proteins to the gI protein of the cyanobiont are found in nonphotosynthetic bacteria, in which carbonic anhydrases are involved in heterotrophic growth and fermentation (Smith and Ferry 2000). The enzyme is also up-regulated 24-fold in Salmonella typhimurium inside its host cell (a macrophage), and a role in intracellular growth and survival has been suggested (Valdivia and Falkow 1997). 


\section{Stress response proteins.}

When endosymbiotic, the growth rate of the cyanobiont is reduced, and it has been speculated that this is regulated by the host. The mechanism is unknown, but one possibility is via a restricted nutrient availability in symbiosis. This is supported by the finding that ferritins (g11 and g19) were up-regulated in the cyanobiont. Members of the Dps family of proteins, including the DpsA up-shifted in the cyanobiont, are ferritins that bind and protect DNA under conditions of nutrient and oxidative stress (Pena and Bullerjahn 1995). One of the upregulated ferritins (g19) was also up-regulated in the heterocyst preparation, indicating a heterocyst-specific function of $\mathrm{g} 19$.
Cysteine synthase (g15) catalyzes the formation of the essential amino acid cysteine. This enzyme is known to be involved in stress response and starvation survival mechanisms in the human Staphylococcus pathogen (Lithgow et al. 2004). In sulfur-limited Bacillus subtilis, the expression of this enzyme is also up-regulated (Coppee et al. 2001). Upregulation of cysteine synthase in the Gunnera cyanobiont may therefore reflect a low-nutrient environment in the Gunnera glands. This may also be the reason for the upregulation of the rhodanese-related sulfurtransferase $(g 7,8)$ in the cyanobiont. The function of these enzymes is unclear, but they have been reported to be involved in biosynthesis, repair of $\mathrm{Fe}-\mathrm{S}$ centers of proteins, or

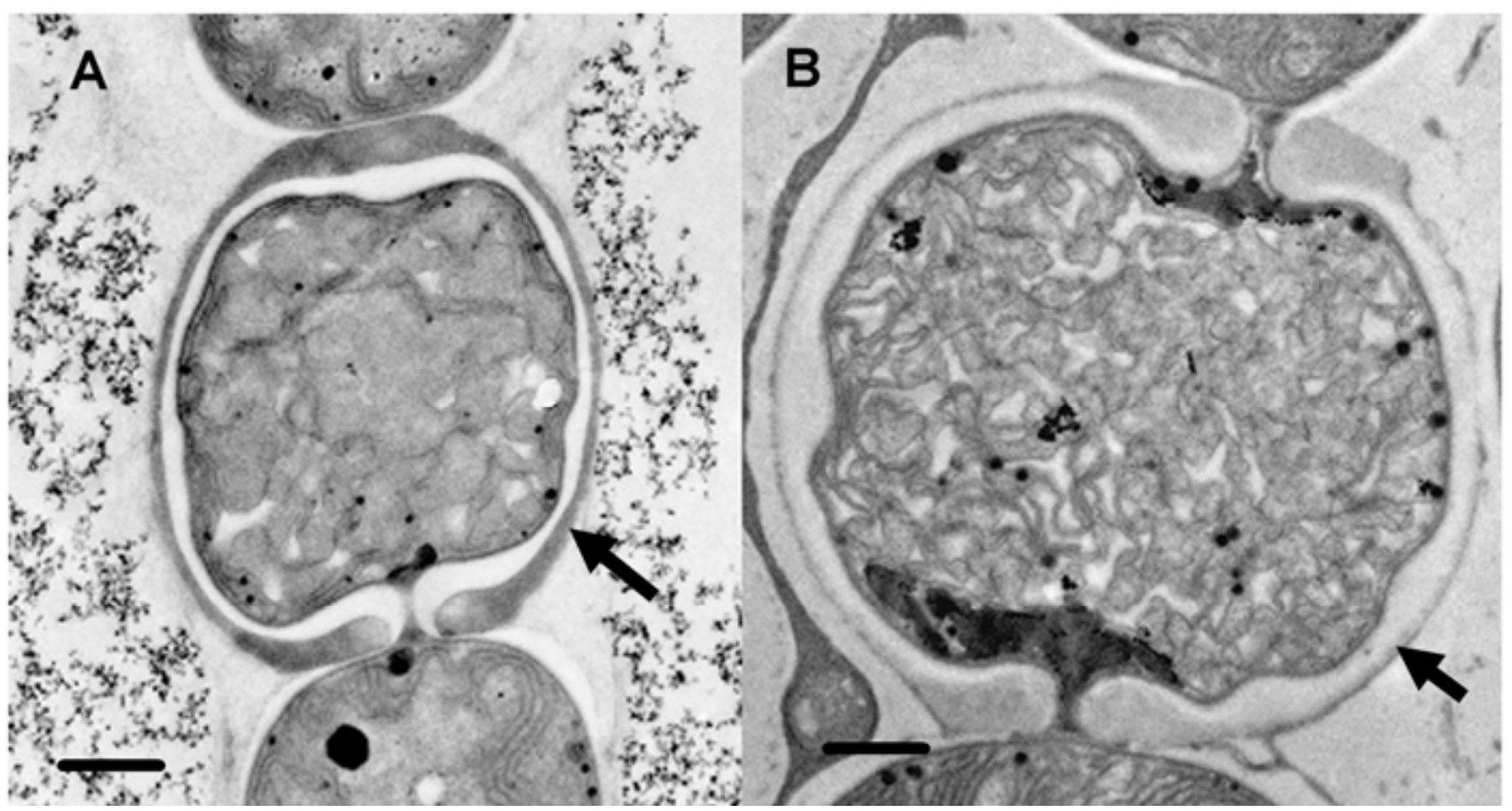

Fig. 5. Transmission electron micrographs of heterocysts of A, free-living Nostoc strain PCC 73102 and B, the symbiotic Nostoc strain occupying Gunnera manicata cells. Note the thinner outer polysaccharide layer (arrows) of the heterocysts in symbiotic Nostoc cells as well as the larger cell size. Bar represents $0.8 \mu \mathrm{m}$.

A

A

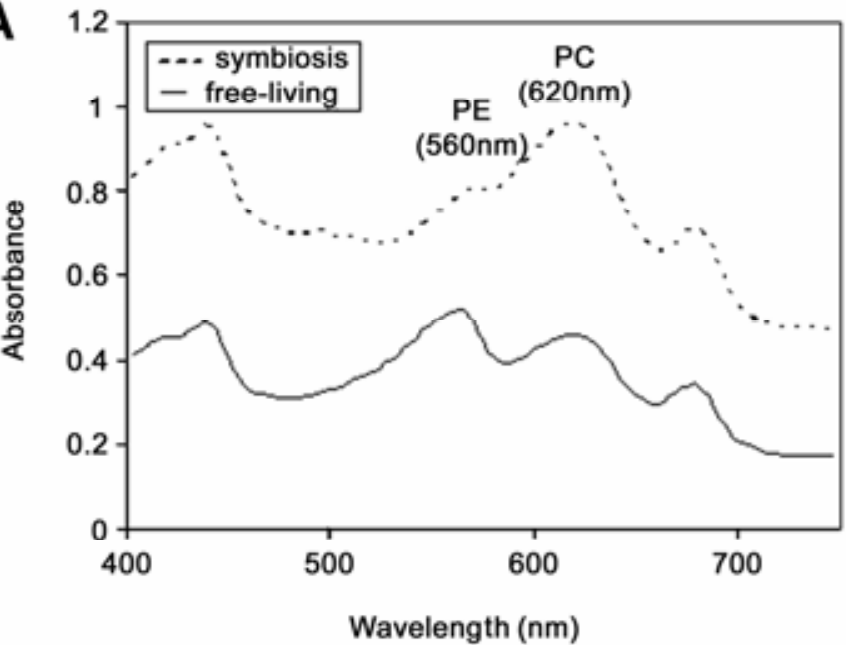

B

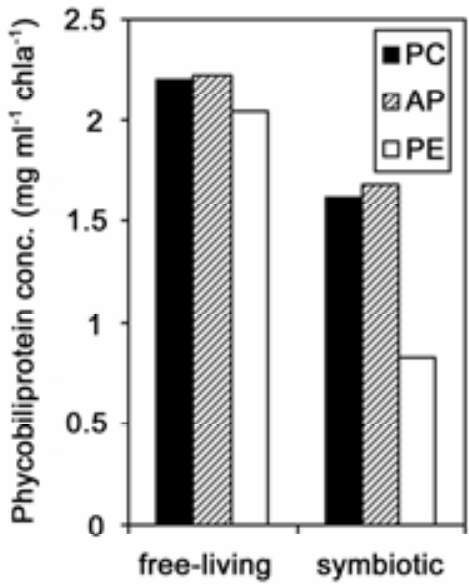

Fig. 6. Phycobiliproteins in free-living and symbiotic Nostoc cells. A, Absorption spectra of soluble phycobiliproteins of free-living Nostoc strain AF, isolated from the Gunnera manicata symbiosis and freshly extracted Nostoc cyanobiont from the same symbiosis. The absorption at 560 nm, corresponding to phycoerythrin (PE), relative to the absorption at $620 \mathrm{~nm}$, corresponding to phycocyanin (PC), is lower in symbiotic than in free-living Nostoc cells. B, When calculating the phycobiliprotein concentration and normalizing it to the chlorophyll a concentration, it is obvious that mainly PE levels decrease in symbiotic Nostoc cells. AP = allophycocyanin. 
both, detoxification mechanisms of the reactive oxygen species, and in assimilatory sulfate reduction (Melino et al. 2004).

Catalases are usually involved in protection against oxidative stress. Since the environment inside the glands is microaerobic, the upregulation of the Mn-catalase $(\mathrm{g} 9,10)$ is unexpected. However, in Rhizobium-legume symbioses, both bacterial catalases and a peroxiredoxin have been reported to be up-regulated despite low-oxygen conditions (Dombrecht et al. 2005). The reason for this upregulation was suggested to be a combination of nutrient and carbon limitation, stationary phase-like growth, a high need to protect nitrogenase, and a high respiration. Heterocysts of free-living cyanobacteria also show a high specific catalase activity (Fay 1992). Another protein involved in the defense against oxidative stress, glutaredoxin (g28), was, on the other hand, down-regulated in the cyanobiont, and it therefore seems as if different sets of stress-response proteins are expressed under symbiotic versus free-living conditions. Alternatively, as glutaredoxin may also be involved in the formation of deoxyribonucleotides for DNA synthesis (Fernandes and Holmgren 2004), the downregulation of this protein in the cyanobiont may be related to a reduced rate of cell division.

\section{Other proteins.}

One of the proteins (g32) up-regulated in the cyanobiont was identified as a homolog to the $\operatorname{orr} A$ response regulator in Anabaena sp. strain PCC 7120 (Schwartz et al. 1998), the expression being stimulated in the presence of various osmotica such as $\mathrm{NaCl}$ or sucrose. An upregulation of this protein in symbiosis may be due to a higher osmotic pressure caused by host-supplied carbohydrates.

As the 'akinete marker' protein (g2), previously found to be highly expressed in akinetes of Anabaena variabilis (Zhou and Wolk 2002), was both up-shifted in the akinete-free cyanobiont of Gunnera and down-regulated in hormogonia of Nostoc strain PCC 73102 (Klint 2003), the function of this protein needs to be redefined. It should also be noted that four homologous copies are present in the Nostoc strain PCC 73102 genome.

\section{Overall perspective.}

When entering Gunnera cells, the normally photoautotrophic genus Nostoc is exposed to a strikingly different environment, such as being intracellular, in darkness, and microaerobiosis. In addition to having to adapt to this environment, Nostoc strains are influenced by the plant in certain ways, reflected in the high heterocyst frequency, the export of fixed nitrogen, and the reduced growth and cell division rates. Our study shows that despite these physiological differences, most of the proteins present in symbiosis are also present in the free-living state, indicating that most cellular functions remain largely intact in symbiosis. This is also verified by the ease with which Nostoc strains, in contrast to, for instance, the Azolla cyanobiont (Rai et al. 2000), resume growth as free-living after being isolated from symbiotic plant tissues.

However, vital adaptations of the cyanobiont that were of symbiotic relevance were observed. The upshift in the key symbiotic process, nitrogen fixation, is clearly reflected in the cyanobiont protein pattern, as is the mechanism by which this process is supplied with energy. An upregulation of the OPP pathway was apparent, while the Calvin cycle, as expected, was down-regulated. A metabolic focus on heterocyst-related metabolism and function is also reflected in the fact that most of the proteins up-regulated in the heterocysts were also upregulated in the cyanobiont. Indeed, the symbiotic conditions offered in planta, i.e., heterotrophy and microaerobiosis, are similar to those already prevailing in heterocysts. One may therefore speculate that adapting to a symbiotic life involves mechanisms already developed for heterocysts.
Several proteins differentially expressed in the cyanobiont were membrane- or surface-related, implicating surface adaptations as being of particular importance for the establishment of the symbiosis and for nutrient exchange, which also is in accordance with our earlier observations (Klint 2003; Liaimer 2002). Downregulation of certain proteins may, furthermore, be related to potential plant- or microaerobiosis-induced changes of the heterocyst cell wall and thereby to the release of ammonia.

A third group of proteins affected were nutrient and oxidative stress related, indicating that the cyanobiont is kept nutrient limited and that this may be a mechanism by which the host regulates the growth rate of the cyanobiont.

In conclusion, our results demonstrate that the proteomic approach is an excellent tool to discover novel and nonpredictable changes and adaptive processes in such complex associations as the one between cyanobacteria and plants. Although the endosymbiotic Nostoc strain investigated has not been sequenced, a high percentage of proteins were identified based on the sequenced genome of Nostoc strain PCC 73102. As this genome is suggested to contain more than 7,000 open reading frames (Meeks et al. 2001), the proteins identified here clearly represent a fraction of all proteins and the full potential of symbiotic-specific plant-induced regulation is still to be identified.

\section{MATERIALS AND METHODS}

\section{Organisms and growth conditions.}

G. manicata Linden plants were grown in the greenhouse at the Department of Botany at Stockholm University (Stockholm, Sweden) at $15^{\circ} \mathrm{C}$. Cyanobacteria isolated from one of these plants (discussed below) and Nostoc strain PCC 73102 were cultivated in nitrogen-depleted $\mathrm{BG} 11_{0}$ medium (Stanier et al. 1971) at constant light $\left(18 \mu \mathrm{mol}\right.$ photons $\left.\mathrm{m}^{-2} \mathrm{~s}^{-2}\right)$ and shaking at $25^{\circ} \mathrm{C}$. For obtaining heterocyst-free Nostoc strain PCC 73102 , this strain was cultivated in $\mathrm{BG} 11_{0}$ with the addition of $2.5 \mathrm{mM} \mathrm{NH}_{4} \mathrm{Cl}$ and was buffered with $5 \mathrm{mM}$ MOPS (morpholinepropanesulfonic acid), $\mathrm{pH} 7.8$.

\section{Isolation of symbiotic Nostoc strains from G. manicata.}

The G. manicata plant stem containing the Nostoc-infected glands was cut free of leaves and other material, was washed with $70 \%$ ethanol followed by sterile water, and then, was divided into two sections, the upper and younger part close to the growing plant apex and the lower, older part. Approximately 35 Nostoc-infected glands from each stem section were cut out using a sterile scalpel, and the Nostoc cells were excised into ice-cold buffer A (1\% [vol/vol] Tween $20,15 \mathrm{mM}$ $\mathrm{MgCl}_{2}$, and 2\% [wt/vol] polyvinylpyrrolidone). The cells were then homogenized with a plastic pestle in a microcentrifuge tube and were allowed to sediment. The supernatant was kept, and the pellet was resuspended in buffer A and allowed to sediment again. This was repeated three times, after which the supernatants were pooled and twice centrifuged for $2 \mathrm{~min}$. at 320 $\times g$. The cells were then dissolved in $2 \mathrm{ml}$ of buffer A and were placed on top of $80 \%$ Percoll (Amersham Biosciences, Uppsala, Sweden) and centrifuged for $20 \mathrm{~min}$ at $800 \times g$ at $4^{\circ} \mathrm{C}$. The cells stayed on top of the Percoll while Gunnera starch grains sedimented. The excised Nostoc cells from all glands of each stem section were pooled and mixed into two samples, A1 and A2 (young and old). Microscopic observation showed that the suspensions were dominated by Nostoc cells, and only a small proportion of plant cell debris was present. The heterocyst frequency was also estimated by light microscopy. The cell suspensions were transferred to microcentrifuge tubes and centrifuged $(15,800 \times g)$, and the pellets were frozen at $-20^{\circ} \mathrm{C}$. Ap- 
proximately $50 \mu \mathrm{l}$ of the A1 suspension was plated on a BG11 agar $(1.5 \%)$ plate and was maintained under the conditions given above. After a few weeks, colonies developed and were transferred to liquid $\mathrm{BG} 11_{0}$ medium. A free-living Nostoc culture obtained in this way was named AF. From this culture, approximately the same amount of cells was harvested from the AF culture as from the symbiotic Nostoc culture $(50 \mathrm{mg}$ wet weight).

\section{Isolation of heterocysts.}

Heterocysts were isolated using a method based on that of Smith and associates (1988). Nostoc strain PCC 73102 was grown in $\mathrm{BG} 11_{0}$ medium under continuous light and stirring in BG11 $1_{0}$ batch cultures of 1 liter. Filaments were collected in the exponential phase by centrifugation, and the pellet was washed twice in buffer A (50 mM Tris-HCl, pH 7.5, 10 mM EDTA, 1 $\left.\mathrm{mM} \mathrm{MgCl}_{2}\right)$ Lysozyme $(1 \mathrm{mg} / \mathrm{ml})$ was added, and the cells were incubated at $37^{\circ} \mathrm{C}$ for $1 \mathrm{~h}$. To fully disrupt the vegetative cells, the suspensions were also exposed to sonication at $70 \%$ intensity for $15 \mathrm{~s}$ and were washed three to four times with buffer A, using a centrifuge speed of $250 \times g$. This usually resulted in approximately $80 \%$ heterocyst enrichment. These heterocyst-enriched pellets were frozen, and proteins were extracted as described below. A pure vegetative cell sample was obtained by culturing Nostoc strain PCC 73102 in BG11 $1_{0}$ medium supplemented with $\mathrm{NH}_{4} \mathrm{Cl}$, as described above.

\section{Protein extraction.}

The cyanobacterial pellets (freshly extracted and cultured cyanobiont and heterocyst enrichments and vegetative cells of Nostoc strain PCC 73102) were frozen in liquid nitrogen, a few grains of acid-washed sand were added, and the cells were ground with a plastic pestle. A total of $200-\mu$ of sample buffer containing $8 \mathrm{M}$ urea, $2 \mathrm{M}$ thiourea, $2.8 \%$ (wt/vol) DTT, protease inhibitor (1 tablet to $10 \mathrm{ml}$ Complete mini; Roche Diagnostics, Mannheim, Germany), and 2\% (wt/vol) CHAPS was then added. The samples were then frozen and thawed three more times in liquid nitrogen. Four samples were pooled, resulting in a total sample volume of $800 \mu$ land were sonicated five times for $3 \mathrm{~s}$ at $70 \%$ intensity with 30 -s intervals on ice to avoid heating. The samples were then centrifuged at 15,800 $\times$ $g$ at $4^{\circ} \mathrm{C}$ for $15 \mathrm{~min}$ to remove remaining cell debris. The supernatant was collected and kept at $-20^{\circ} \mathrm{C}$ until use. The protein concentration in the samples was determined using the RC DC kit (BioRad, Hercules, CA, U.S.A.). Proteins were also extracted from the noninfected Gunnera tissue surrounding the symbiotic glands, using the same procedure.

\section{2-D gel electrophoresis.}

Isoelectric focusing of the proteins was performed using the IPGphore system (Amersham Biosciences). Immobiline gel strips (18 cm, $\mathrm{pH} 4$ to 7$)$ were rehydrated overnight in the same buffer as that used for protein extraction, with the addition of $0.5 \%$ immobilized $\mathrm{pH}$ gradient buffer. Protein extract containing $150 \mu \mathrm{g}$ of protein was applied to the gel strip by using application cups located at the acidic end of the strip. The proteins were separated by applying voltage as follows: $500 \mathrm{~V}$ for $30 \mathrm{~min}, 1,500 \mathrm{~V}$ for $1.5 \mathrm{~h}$, and $8,000 \mathrm{~V}$ until reaching a total of 75,000 $\mathrm{Vh}$. The strips were then incubated in equilibration buffer (50 mM Tris- $\mathrm{HCl}, \mathrm{pH} 8.8,6 \mathrm{M}$ urea, 30\% [vol/vol] 87\% glycerol [vol/vol], 2\% [wt/vol] SDS) with $1 \%$ (wt/vol) DTT added for $15 \mathrm{~min}$, and subsequently, in equilibration buffer with $4 \%$ (wt/vol) iodoacetamide added. The proteins were then separated according to size in a $10 \%$ acrylamide gel run at $10 \mathrm{~V}$ per gel for $30 \mathrm{~min}$ and then for $25 \mathrm{~V}$ per gel for approximately $4.5 \mathrm{~h}$. The gels were stained with SyproRuby (BioRad) according to the manufacturer's instructions, and a
Typhoon 8600 laser scanner was used to visualize the gels (Amersham Biosciences). To obtain quantitative estimates of the protein spots, the scanned 2-D protein patterns were analyzed by PDQuest software (BioRad). Three replica gels of each treatment were included in the analysis, and protein spots were only further analyzed if a consistent change in abundance of two times or more was observed.

\section{In-gel digestion and MS.}

In-gel tryptic digestion was performed according to Gharahdaghi and associates (1999). Mass spectra were obtained using a Voyager-DE STR mass spectrometer operating in reflective mode (MALDI-TOF; Applied Biosystems, Foster City, CA, U.S.A.). Two-point internal calibration of the peptide mass fingerprints was achieved using internal trypsin autolysis peptides and MoverZ software, available online from Genomic Solutions (Ann Arbor, MI, U.S.A.). The obtained peak lists were compared with databases, using the Mascot search engine available online from Matrix Science (Boston). NCBInr was chosen as sequence database, taxonomy was set to all organisms, a mass tolerance was set to $30 \mathrm{ppm}$, fixed modifications was set to alkylation of cysteine by carbamidomethylation, and variable modifications to oxidation of methionine. Only peptides with a probability-based Mowse score above 76, indicating a significance level of $P<0.05$, were considered to be successful identifications.

Electrospray-MS/MS experiments were carried out using a Micromass Q-ToF (Waters, Milford, MA, U.S.A.). Prior to analysis, salts and contaminants were removed from the samples by ZipTip purification and the peptides were eluted in water/ acetonitrile (1:1) with $0.1 \%$ of formic acid. Samples ( 1 to $3 \mu \mathrm{l})$ were loaded into a nanospray tip (Proxeon, Odense, Denmark). The capillary voltage was kept at 1,200 to $1,300 \mathrm{~V}$ and the cone voltage at 45 . Argon was used as collision gas at an inlet pressure of 0.7 Bar, and fragmentation was achieved by increasing the collision energy to 20 to 35 . Doubly charged ions were selected for fragmentation and tandem mass spectra were acquired for 1 to $10 \mathrm{~min}$. The spectra were processed with MassLynx MaxEnt 3 before database searches in NCBInr utilizing Mascot. Proteins g3 and g29 were not identified by this procedure and were therefore sequenced de novo, using the processed tandem mass spectra and the BioLynx peptide sequencing tool (Micromass). All suggested sequences for all fragmented peptides were submitted to MS-Homology from ProteinProspector, available online from the University of California, San Francisco.

\section{DNA extraction and PCR amplification.}

DNA was extracted, using the GenElute plant genomic DNA miniprep kit (Sigma-Aldrich, St. Louis), from the following samples: symbiotic Nostoc cells freshly excised from two different $G$. manicata stem sections described above and denoted A1 and A2; the free-living Nostoc culture AF from the same stem glands described above; symbiotic Nostoc cells excised from the small stoloniferous G. magellanica (B1 and B2) from the same greenhouse (Department of Botany, Stockholm University); another free-living Nostoc culture previously isolated from G. magellanica (Nostoc BF); axenic culture of Nostoc strain PCC 9229 (originally isolated by E. Söderbäck from Gunnera monoica in New Zeeland).

The oligonucleotide STRR1A (5'-CCARTCCCCARTCCCC$\left.3^{\prime}\right)$, corresponding to a short tandemly repeated repetitive (STRR) sequence present in the genome of heterocystous cyanobacteria (Rasmussen and Svenning 1998), was used as a primer in the PCR to obtain DNA fingerprints from these cyanobacteria. The PCR reaction volume was $25 \mu$, and each reaction contained $1 \mathrm{U}$ polymerase (DynaZyme, Finnzymes, Oy, 
Finland), $1 \times$ buffer (supplied with the enzyme), $1.25 \mathrm{mM}$ of each dNTP, 50 pmol STRR1A primer, and 50 ng of DNA template. PCR reactions were run under the following conditions: 1 cycle at $95^{\circ} \mathrm{C}$ for $6 \mathrm{~min}, 40$ cycles at $94^{\circ} \mathrm{C}$ for $1 \mathrm{~min}, 56^{\circ} \mathrm{C}$ for $1 \mathrm{~min}, 65^{\circ} \mathrm{C}$ for $5 \mathrm{~min}, 1$ cycle at $65^{\circ} \mathrm{C}$ for $16 \mathrm{~min}$, and a final step at $4^{\circ} \mathrm{C}$. Amplification products $(10 \mu \mathrm{l})$ were separated in $1.5 \%$ agarose gels. The gels were stained with ethidium bromide and were visualized by UV light and recorded with a CCD video camera (VC-XC-75CE, Sony, Tokyo).

\section{Sequencing of the tRNA ${ }^{\text {Leu }}$ (UAA) intron.}

The tRNA ${ }^{\text {Leu }}$ (UAA) intron was amplified by a nested PCR reaction with the outer primers $\mathrm{A}$ and $\mathrm{C}$ as described by Paulsrud and Lindblad (1998) and the inner primers TL25 and TL23 as described by Biniszkiewicz and associates (1994). As template, $1 \mu \mathrm{l}$ of the same DNA as above was used in the first PCR reaction. The PCR products were purified using a commercial kit (Quiaquick PCR purification kit; Qiagen $\mathrm{GmbH}$, Hilden, Germany) and the DNA fragments sequenced by DNA Technology (Aarhus, Denmark). The sequences were edited and compared using the BioEdit software, available online from North Carolina State University.

\section{Light and transmission electron microscopy.}

To analyze extracellular carbohydrates, cyanobionts freshly extracted from $G$. manicata glands and its free-living counterpart Nostoc strain AF were stained with $1 \%$ aqueous solution of Alcian blue for $40 \mathrm{~s}$, were washed with deionized water, and were examined using light microscopy (Olympus BX60, Olympus, Tokyo). To examine cell wall structures and extracellular carbohydrates in more detail, the same samples were stained with $15 \%$ Ruthenium red for $1 \mathrm{~h}$, followed by immobilization of cell pellets in 2\% agar. Agar blocks were then dehydrated through an ethanol series up to $100 \%$ and embedded in Epon 812 (TAAB). Ultrathin sections on gold grids were examined using transmission electron microscopy (Zeiss EM106, Oberkochen, Germany) operating at $60 \mathrm{kV}$.

\section{Chlorophyll and phycobiliprotein determination.}

Phycobiliproteins were extracted from the cyanobacterial samples by the same procedure given above for total protein extractions, except that the sample buffer was substituted with a $20 \mathrm{mM}$ sodium acetate buffer. The absorbance spectra of the extracts were scanned using spectroscopy (Ultrospec 3000, Pharmacia Biotech, Uppsala, Sweden) within a range of 400 to $750 \mathrm{~nm}$. The phycobiliprotein concentrations were calculated using equations given by Tandeau de Marsac and Houmard (1988). The pellet remaining after centrifugation was incubated on ice in darkness for $1 \mathrm{~h}$ in methanol to extract chlorophyll a, and the absorbance of the supernatant was measured at $665 \mathrm{~nm}$.

\section{ACKNOWLEDGMENTS}

The financial support by The Swedish Research Council (to B. Bergman) is gratefully acknowledged, as is the European Science Foundation CYANOFIX program (to M. Ekman).

\section{LITERATURE CITED}

Austin, P. A., Ross, I. S., and Mills, J. D. 1996. Regulation of pigment content and enzyme activity in the cyanobacterium Nostoc sp. Mac grown in continuous light, a light-dark photoperiod, or darkness. Biochim. Biophys. Acta 1277:141-149.

Bahat-Samet, E., Castro-Sowinski, S., and Okon, Y. 2004. Arabinose content of extracellular polysaccharide plays a role in cell aggregation of Azospirillum brasiliense. FEMS (Fed. Eur. Microbiol. Soc.) Microbiol. Lett. 237:195-203.

Bergman, B. 2002. The Nostoc-Gunnera symbiosis. Pages 207-232 in: Cyanobacteria in Symbiosis. A. N. Rai, B. Bergman, and U. Rasmus- sen, eds. Kluwer Academic Publishers, Dordrecht, The Netherlands.

Bergman, B., Johansson, C., and Söderbäck E. 1992. The Nostoc-Gunnera symbiosis. New Phytol. 122:379-400.

Biniszkiewicz, D., Cesnaviciene, E., and Shub, D.A. 1994. Self-splicing group I intron in cyanobacterial initiator methionine tRNA: Evidence for lateral transfer of introns in bacteria. EMBO (Eur. Mol. Biol. Organ.) J. 13:4629-35.

Black, K. G., Parsons, R., and Osborne, B. A. 2002. Uptake and metabolism of glucose in the Nostoc-Gunnera symbiosis. New Phytol. 153:297-305.

Broedel, S. E., and Wolf, R. E. 1991. Growth-phase-dependent induction of 6-phosphogluconate dehydrogenase and glucose 6-phosphate dehydrogenase in the cyanobacterium Synechococcus sp. PCC 7942. Gene. 109:71-9.

Buikema, W. J., and Haselkorn, R. 1991. Characterization of a gene controlling heterocyst differentiation in the cyanobacterium Anabaena 7120. Genes Dev. 5:321-330.

Chatfield, C. H., Koo, H., and Quivey, R. G. 2005. The putative autolysin regulator LytR in Streptococcus mutans plays a role in cell division and is growth phase regulated. Microbiol. 151:625-631.

Coppee, J. Y., Auger, S., Turlin, E., Sekowska, A., Le Caer, J. P., Labas, V. Vagner. V., Danchin, A., and Martin-Verstraete, I. 2001. Sulfur-limitation-regulated proteins in Bacillus subtilis: A two-dimensional gel electrophoresis study. Microbiol. 147:1631-40.

Coyne, M. J., Russel, K. S., Coyle, C. L., and Goldberg, J. B. 1994. The Pseudomonas aeruginosa algC gene encodes phosphoglucomutase, required for the synthesis of a complete lipopolysaccharide core. J. Bacteriol. 176:3500-3507.

Dombrecht, B., Heusdens, C., Beullens, S., Verreth, C., Mulkers, E., Proost, P., Vanderleyden, J., and Michiels, J. 2005. Defence of Rhizobium etli bacteroids against oxidative stress involves a complexly regulated atypical 2-cys peroxiredoxin. Mol. Microbiol. 55:1207-1221.

Fay, P. 1992. Oxygen relations of nitrogen fixation in cyanobacteria. Microbiol. Rev. 56:340-373.

Fernandes, A. P., and Holmgren, A. 2004. Glutaredoxins:glutathione-dependent redox enzymes with functions far beyond a simple thioredoxin backup system. Antioxid. Redox. Signal 6:63-74.

Flores, E., and Herrero, A. 2005. Nitrogen assimilation and nitrogen control in cyanobacteria. Biochem. Soc. Trans. 33:164-7.

Gharahdaghi, F., Weinberg, C. R., Meagher, D. A., Imai, B. S., and Mische, S. M. 1999. Mass spectrometric identification of proteins from silver-stained polyacrylamide gel: A method for the removal of silver ions to enhance sensitivity. Electrophoresis 20:601-605.

Guevara, R., Armesto, J. J., and Caru, M. 2002. Genetic diversity of Nostoc microsymbionts from Gunnera tinctoria revealed by PCRSTRR fingerprinting. Microbiol. Ecol. 44:127-136.

Huang, G., Fan, Q., Lechno-Yossef, S., Wojciuch, E., Wolk, C. P., Kaneko, T., and Tabata, S. 2005. Clustered genes required for the synthesis of heterocyst envelope polysaccharide in Anabaens sp. strain PCC 7120. J. Bacteriol. 187:1114-1123.

Johansson, C., and Bergman, B. 1992. Early events during the establishment of Gunnera/Nostoc symbiosis. Planta 188:403-413.

Kangatharalingam, N., Priscu, J. C., and Pearl, H. W. 1992. Heterocyst envelope thickness, heterocyst frequency and nitrogenase activity in Anabaena flos-aquae: Influence of oxygen tension. J. Gen. Microb. 138:2673-2678.

Kereszt, A., Kiss, E., Reuhs, B. L., Carlson, R. W., Kondorosi, A., and Putnoky, P. 1998. Novel rkp gene clusters of Sinorhizobium meliloti involved in capsular polysaccharide production and invasion of the symbiotic nodule: The $r k p K$ gene encodes a UDP-glucose dehydrogenase. J. Bacteriol. 180:5426-31.

Klint, J. 2003. Protein variation during cyanobacterial cell division and differentiation. Ph.D. thesis, Stockholm University, Stockholm, Sweden.

Leitao, J. H., and Sa-Correia, I. 1997. Oxygen-dependent upregulation of transcription of alginate genes $\operatorname{alg} A$, algC and $\operatorname{alg} D$ in Pseudomonas aeruginosa. Res. Microbiol. 148:37-43.

Liaimer, A. 2002. Molecular communication and responses in Nostoc-plant symbioses. Ph.D. thesis, Stockholm University, Stockholm, Sweden.

Lithgow, J. K., Hayhurst, E. J., Cohen, G., Aharonowitz, Y., and Foster, S. J. 2004. Role of cysteine synthase in Staphylococcs aureus. J. Bacteriol. 186:1579-1590.

Martin, W., Rujan, T., Richly, E., Hansen, A., Cornelsen, S., Lins, T., Leister, D., Stoebe, B., Hasegawa, M., and Penny D. 2002. Evolutionary analysis of Arabidopsis, cyanobacterial, and chloroplast genomes reveals plastid phylogeny and thousands of cyanobacterial genes in the nucleus. Proc. Natl. Acad. Sci. U.S.A. 99:12246-12251.

Meeks, J. C., Elhai, J., Thiel, T., Potts, M., Larimer, F., Lamerdin, J., Predki, P., and Atlas, R. 2001. An overview of the genome of Nostoc punctiforme, a multicellular, symbiotic cyanobacterium. Photosynth. Res. 70:85-106. 
Melino, S., Cicero, D. O., Forlani, F., Pagani, S., and Paci, M. 2004. The $\mathrm{N}$-terminal rhodanese domain from Azotobacter vinelandii has a stable and folded structure independently of the C-terminal domain. FEBS (Fed. Eur. Biochem. Soc.) Lett. 577:403-408

Nikolskaya, A. N., and Galperin, M. Y. 2002. A novel type of conserved DNA-binding domain in the transcriptional regulators of the AgR/AgrA/LytR family. Nucleic Acid Res. 30:2453-2459.

Nilsson, M., Bergman, B., and Rasmussen, U. 2000. Cyanobacterial diversity in geographically related and distant host plants of the genus Gunnera. Arch. Microbiol. 173:97-102.

Otero, A., and Vincenzini, M. 2003. Extracellular polysaccharide synthesis by Nostoc strains as affected by $\mathrm{N}$ source and light intensity. J. Biotechnol. 102:143-152.

Otero, A., and Vincenzini, M. 2004. Nostoc (Cyanophyceae) goes nude: Extracellular polysaccharides serve as a sink for reducing power under unbalanced C/N metabolism. J Phycol. 40:74-81.

Paulsrud, P., and Lindblad, P. 1998. Sequence variation of the tRNA(Leu) intron as a marker for genetic diversity and specificity of symbiotic cyanobacteria in some lichens. Appl. Environ. Microbiol. 64:310-315.

Paulsrud, P., and Lindblad, P. 2002. Fasciclin domain proteins are present in Nostoc symbionts of lichens. Appl. Environ. Microb. 68:2036-2039.

Pena, M. M. O., and Bullerjahn, G. S. 1995. The DpsA protein of Synechococcus sp strain-PCC7942 is a DNA-binding hemoprotein. J. Biol. Chem. 270:22478-22482.

Rai, A. N., Söderbäck, E., and Bergman, B. 2000. Cyanobacterium-plant symbiosis. New Phytol. 147:449-481.

Rasmussen, U., and Svenning, M. M. 1998. Fingerprinting of cyanobacteria based on PCR with primers derived from short and long tandemly repeated repetitive sequences. Appl. Environ. Microb. 64:265-272.

Schopf, J. W. 2000. The fossil record: Tracing the roots of the cyanobacterial lineage. Pages 13-35 in: The Ecology of Cyanobacteria. B. A Whitton and M. Potts, eds. Kluwer Academic Publishers, Dordrecht, The Netherlands.

Schwartz, S. H., Black, T. A., Jager, K., Panoff, J. M., and Wolk, C. P. 1998. Regulation of an osmoticum-responsive gene in Anabaena sp. strain PCC 7120. J. Bacteriol. 180:6332-6337.

Shevchenko, A., Sunyaev, S., Loboda, A., Shevchenko, A., Bork, P., Ens, W., and Standing, K.G. 2001. Charting the proteomes of organisms with unsequenced genomes by MALDI-Quadrupole Time-of-Flight mass spectrometry and Blast homology searching. Anal. Chem. 73:1917-1926.

Silvester, W. B., Parsons, R., and Watt, P. W. 1996. Direct measurement of release and assimilation of ammonia in the Gunnera-Nostoc symbiosis. New Phytol. 132:617-625.

Smith, K. S., and Ferry, J. G. 2000. Prokaryotic carbonic anhydrases. FEMS (Fed. Eur. Microbiol. Soc.) Microbiol Rev. 24:335-66.

Smith, R. L., van Baalen, C., and Tabita, F. R. 1988. Isolation of metabolically active heterocysts from cyanobacteria. Methods Enzymol. 167:490-495

Söderbäck, E. 1992. Developmental patterns in the Nostoc-Gunnera symbiosis. Ph.D. thesis. Stockholm University, Stockholm, Sweden.

Söderbäck, E., and Bergman, B. 1992. The Nostoc-Gunnera magellanica symbiosis-Phycobiliproteins, carboxysomes and Rubisco in the cyanobiont. Physiol. Plant. 84:425-432.

Söderbäck, E., and Bergman, B. 1993. The Nostoc-Gunnera symbiosis:
Carbon fixation and translocation. Physiol. Plant. 89:125-132.

Söderbäck, E., Lindblad, P., and Bergman, B. 1990. Developmental patterns related to nitrogen fixation in the Nostoc-Gunnera magellanica Lam. symbiosis. Planta 182:355-362.

Stanier, R. Y., Kunisawa, R., Mandel, M., and Cohen-Bazire, G. 1971. Purification and properties of unicellular blue-green algae (Order Chroococcales). Bacteriol. 35:171-205.

Summers, M. L., and Meeks, J. C. 1996. Transcriptional regulation of zwt, encoding glucose-6-phosphate dehydrogenase, from the cyanobacterium Nostoc punctiforme strain ATCC 29133. Mol. Microbiol. 22:473480.

Summers, M. L., Wallis J. G, Campbell E. L, and Meeks J. C. 1995. Genetic evidence of a major role for glucose-6-phosphate dehydrogenase in nitrogen fixation and dark growth of the cyanobacterium Nostoc sp. strain ATCC 29133. J. Bacteriol. 177:6184-6194.

Tamoi, M., Murakami, A., Takeda, T., and Shigeko, S. 1998. Acquisition of a new type of fructose-1,6-bisphosphatase with resistance to hydrogen peroxide in cyanobacteria: Molecular characterization of the enzyme from Synechocystis PCC 6803. Biochim. Biophys. Acta 1383:232-244.

Tandeau de Marsac, N., and Houmard, J. 1988. Complementary chromatic adaptation: Physiological conditions and action spectra. Method. Enzymol. 167:318-328.

Valdivia, R. H, and Falkow, S. 1997. Fluorescence-based isolation of bacterial genes expressed within host cells. Science 277:2007-2011.

Wang, C-M., Ekman, M., and Bergman, B. 2004. Expression of cyanobacterial genes involved in heterocyst differentiation and dinitrogen fixation along a plant symbiosis development profile. Mol. Plant Microbe Interact. 17:436-443.

Westphal, S., Heins, L., Soll, J., and Vothknecht, U. C. 2001. Vipp1 deletion mutant of Synechocystis: A connection between bacterial phage shock and thylakoid biogenesis? Proc. Natl. Acad. Sci. U.S.A. 98:4238 4242 .

Wolk, C. P., Ernst, A., and Elhai, J. 1994. Heterocyst metabolism and development. Pages 769-823 in: The Molecular Biology of Cyanobacteria. D. A. Bryant, ed. Kluwer Academic Publishers, Dordrecht, The Netherlands.

Xue, G., Penney, L. C., van de Rijn, I., and Tanner, M. E. 2004. Active site residues and mechanism of UDP-glucose dehydrogenase. Eur. J. Biochem. 271:14-22.

Zhou, R. B., and Wolk, C. P. 2002. Identification of an akinete marker gene in Anabaena variabilis. J. Bacteriol. 184:2529-2532.

\section{AUTHOR RECOMMENDED INTERNET RESOURCES}

Department of Energy Joint Genome Initiative website: www.jgi.doe.gov Genomic Solutions website: www.genomicsolutions.com

Matrix Science Mascot website: www.matrixscience.com

National Center for Biotechnology Information website: www.ncbi.nlm.nih.gov

North Carolina State University, BioEdit website: www.mbio.ncsu.edu/BioEdit/bioedit.html

University of California San Francisco, MS-Homology, ProteinProspector website: prospector.ucsf.edu 